\title{
ANALISIS KESIAPAN DAN PELAKSANAAN \\ PERKULIAHAN AKUNTANSI BERBASIS KONVERGENSI INTERNATIONAL FINANCIAL REPORTING STANDARTS (IFRS)
}

\author{
Sigit Hermawan \\ Ety Nur Zunaida \\ Universitas Muhammadiyah Sidoarjo \\ tigis_her@yahoo.com
}

\begin{abstract}
The aim of the study is to analyze the preparedness and the implementation of accounting class based on IFRS convergence on accounting course of university " $X$ " of Sidoarjo and the "X" school of economics in Surabaya. This research is qualitative by using interpretive paradigm. The data collection techniques used in this research are interview, observation, and documentation. The data validity of this research are credibility, transferability, and dependability. The data analysis used in this research are collection, reduction, display, and conclusion. Results of this research show that the accounting course of university "X" of Sidoarjo is specially not apply the lectures based on IFRS convergence and still in the process of preparing a new curriculum based on IFRS convergence. Meanwhile, the "Y" school of economics of Surabaya has already prepared and applied the lectures on IFRS convergence on some particular subjects.
\end{abstract}

Keywords : Accounting Class, IFRS Convergence, Accounting Program

\begin{abstract}
Abstact: Tujuan penelitian ini adalah untuk menganalisis kesiapan dan pelaksanaan perkuliahan akuntansi berbasis konvergensi IFRS pada program studi Akuntansi Universitas "X" Sidoarjo dan STIE "Y" di Surabaya. Jenis dan paradigma penelitian adalah kualitatif dengan paradigma interpretif. Teknik pengumpulan data dengan cara wawancara, observasi, dan dokumentasi. Keabsahan data dengan credibility, transferability, dan dependability. Analisis data dengan tahapan data collection, reduction, display, dan conclusion. Hasil penelitian menunjukkan bahwa program studi akuntansi Universitas "X" Sidoarjo secara khusus belum menerapkan perkuliahan berbasis konvergensi IFRS dan masih dalam proses mempersiapkan kurikulum baru yang berbasis konvergensi IFRS. Sementara itu, program studi akuntansi STIE "Y" Surabaya telah siap dan telah menerapkan perkuliahan berbasis konvergensi IFRS pada matakuliah tertentu.
\end{abstract}

Kata Kunci : Perkuliahan Akuntansi, Konvergensi IFRS, Program Studi Akuntansi. 
Seiring dengan perkembangan bisnis dalam skala nasional dan intemasional, Ikatan Akuntan Indonesia (IAI) telah mencanangkan dilaksanakannya program konvergensi International Financial Reporting Standards (IFRS) yang diberlakukan secara penuh pada 1 Januari 2012. Hal ini diputuskan setelah melakukan pengkajian dan penelaahan yang mendalam dengan mempertimbangkan seluruh risiko dan manfaat konvergensi terhadap IFRS. Dengan adanya standar global tersebut, memungkinkan perbandingan dan pertukaran informasi secara universal.

Untuk dapat segera mengaplikasikan IFRS di Indonesia, berbagai usaha sosialisasi telah dilakukan termasuk oleh IAI seperti program sertifikasi PSAK (CPSAK), sertifikasi pengajar IFRS, training IFRS, pertemuan forum dosen akuntansi keuangan, dan upaya lainnya. Pendidikan akuntansi, di semua level, tidak luput menjadi sasaran utama program penyuksesan konvergensi IFRS. Oleh karena itu, banyak universitas yang mengubah kurikulumnya dengan memasukkan kandungan IFRS dan melatih dosennya agar siap memberikan perkuliahan konvergensi IFRS bahkan mengganti buku teks dengan edisi IFRS. Karena bagaimanapun juga konvergensi IFRS merubah dengan sangat signifikan proses pembelajaran akuntansi di Indonesia. Proses pembelajaran akuntansi harus disesuaikan dengan tujuan utama agar mahasiswa memiliki pengetahuan dan ketrampilan tentang IFRS (Istiningrum, 2012).

Sejalan dengan hal tersebut, dosen dan program studi akuntansi adalah pihak yang paling berperan dalam menyiapkan tenaga professional akuntansi yang memahami konvergensi IFRS. Berbagai upaya juga telah dilakukan oleh program studi akuntansi untuk mempersiapkan diri baik dengan kurikulum maupun dosen yang akan melaksanakan kurikulum dalam proses pembelajaran. Namun menurut hasil penelitian Widiastuti (2011), kesiapan dosen akuntansi untuk mengintegrasikan materi IFRS dalam perkuliahan masih relatif rendah, demikian pula dengan dukungan program studi untuk memfasilitasi dosen mengajarkan IFRS juga masih relatif rendah. Dengan melihat situasi yang seperti ini, akan sangat menarik untuk melakukan penelitian tentang analisis kesiapan dan pelaksanaan perkuliahan akuntansi berbasis konvergensi IFRS.

\section{Analisis Kesiapan}

Menurut Slameto (2003:113), pengertian kesiapan adalah keseluruhan kondisi seseorang yang membuatnya siap untuk memberi respons atau jawaban di dalam cara 
tertentu terhadap suatu situasi. Kesediaan itu timbul dari dalam diri seseorang dan juga berhubungan dengan kematangan, karena kematangan berarti kesiapan untuk melaksanakan kecakapan. Penyesuaian kondisi pada suatu saat akan berpengaruh pada atau kecenderungan untuk memberi respons. Kondisi mencakup setidak-tidaknya 3 aspek, yaitu kondisi fisik meliputi mental dan emosional, kebutuhan-kebutuhan meliputi motif dan tujuan dan keterampilan, pengetahuan dan pengertian yang lain yang telah dipelajari.

Prinsip-prinsip kesiapan menurut Slameto (2003:177) yaitu semua aspek perkembangan berinteraksi (saling pengaruh memengaruhi), kematangan jasmani dan rohani adalah perlu untuk memperoleh manfaat dari pengalaman, pengalamanpengalaman mempunyai pengaruh yang positif terhadap kesiapan, kesiapan dasar untuk kegiatan tertentu terbentuk dalam periode tertentu selama masa pembentukan dalam masa perkembangan.

Faktor-faktor yang mempengaruhi kesiapan menurut Soemanto (1995:189) terdiri dari dua faktor yaitu internal dan ekterna. Faktor internal adalah faktor yang berasal dari dalam diri seseorang, yang terbagi menjadi dua faktor yaitu jasmaniah dan psikologis. Dimana keduanya mempengaruhi seseorang untuk menjadi yang terampil dan siap. Yang termasuk faktor jasmaniah adalah bagaimana kondisi fisik dan panca indranya, sedangkan yang termasuk ke dalam kondisi psikologis adalah minat, tingkat kecerdasan, bakat, motivasi dan kemampuan kognitif. Faktor eksternal adalah faktor yang datang dari luar diri seseorang, diantaranya faktor lingkungan dalam (gedung, fasiitas pembelajaran, hubungan timbal balik antara pendidik dan peserta didik), faktor lingkungan luar (keamanan lingkungan sekitar, tempat belajar, kehidupan bersosial, adat istiadat dan budaya setempat) dan faktor sistem instruksi: kurikulum, bahan pembelajaran dan metode pembelajaran.

\section{Tri Dharma Menuju IFRS}

Bagaimanapun juga program studi akuntansi harus mempersiapkan diri untuk melakukan pembelajaran konvergensi IFRS. Walaupun lepas dari pro dan kontra terhadap IFRS maupun ketiadaan data tentang kesiapan Indonesia melaksanakan IFRS, perguruan tinggi (PT) seharusnya mampu secara obyektif dan proporsional merespon PSAK bercita rasa IFRS. PT seharusnya bisa memberi manfaat besar kepada 
masyarakat termasuk masyarakat bisnis dengan mencipta dan menyebarluaskan pengetahuan dan teknologi (standar akuntansi). Kebutuhan masyarakat bisnis akan tenaga terampil IFRS sangat besar dan akan terus tumbuh. Hal ini menjadi kesempatan dan tantangan tersendiri yang harus dapat ditangkap oleh unit pendidikan program vokasi melalui perubahan kurikulum yang memasukkan materi PSAK-IFRS dalam pengajaran matakuliah-matakuliah akuntansi keuangan (Supriyadi, 2013).

Tentang PT yang harus memberikan manfaat pada masyarakat termasuk pendidikan vokasi akuntansi, hal tersebut sejalan dengan pesan yang tertulis dalam situs dikti.go.id. "Perguruan tinggi sebagai lembaga merupakan komunitas hidup dinamik dalam perannya menumbuh-dewasakan kadar intelektual, emosional dan spiritual para mahasiswa, bergumul dengan nilai-nilai kehidupan kemasyarakatan, mengejar dan mendiseminasikan pengetahuan sebagai pengabdian bagi kemajuan masyarakat. Dalam posisi dan perannya ini, lembaga pendidikan tinggi merupakan mercu suar kebijakan dan kemaslahatan, tidak seperti menara gading yang merupakan monumen mati sebagai simbol belaka". Respon perguruan tinggi terhadap IFRS bisa dilakukan melalui tri dharma perguruan tinggi yaitu pendidikan, penelitian, dan pengabdian kepada masyarakat (Suhardianto, 2011:5).

\section{Pelaksanaan Pendidikan Akuntansi Menuju IFRS}

Akademisi akuntansi yang ingin menghasilkan lulusan yang bermanfaat bagi masyarakat bisnis seharusnya menyiapkan ruang untuk IFRS, meskipun tidak selalu berarti mengajarkan IFRS maupun bermakmum pada DSAK. Ruang yang disediakan tentu bergantung pada tingkat pendidikan, kompetensi lulusan yang ingin dicapai, dan target pasar lulusan (Suhardianto, 2011). Walaupun target lulusan belum tentu bekerja di perusahaan go publik namun pengenalan materi IFRS harus tetap perlu diberikan (Herawati, 2011). Hal tersebut tentunya membawa konsekuensi bahwa lembaga pendidikan akuntansi harus menyiapkan mereka agar siap menghadapi perubahan. Untuk itu kesiapan tenaga pengajar yang memahami konvergensi IFRS sangat diperlukan untuk mewujudkan pembelajaran akuntansi yang berbasiskan IFRS. Hal ini memerlukan komitmen dan kerja sama tim pengajar di institusi masing-masing.

Materi IFRS tidak seharusnya berada di ranah matakuliah pilihan karena kepastian adopsi IFRS dan kebutuhan masyarakat terhadap 'pakar' IFRS sudah nyata. Bagan 
dibawah ini bisa menjadi pedoman menampung IFRS dalam kurikulum akuntansi keuangan.

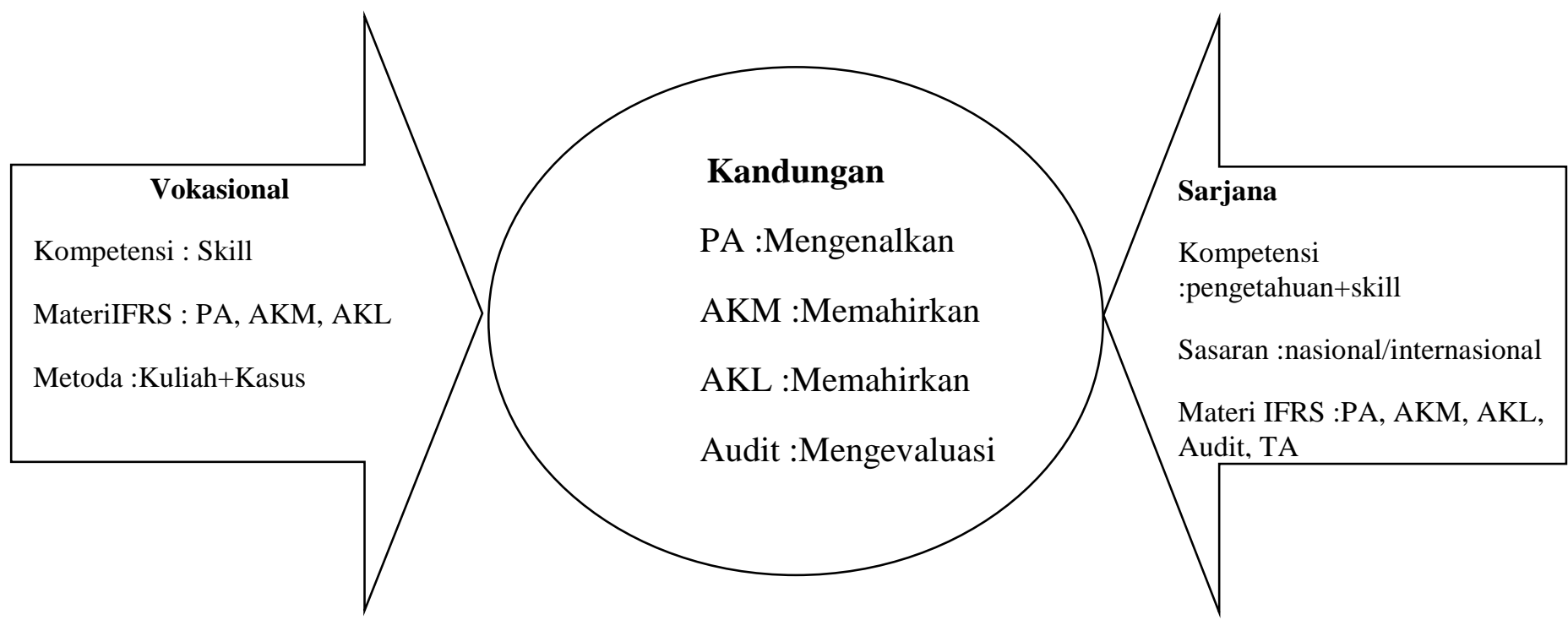

Gambar 1.

Matakuliah Berbasis Konvergensi IFRS

Sumber : Suhardianto (2011)

Setiap jenjang pendidikan memiliki kekhasan dalam memberikan ruang terhadap IFRS. Selain itu, kandungan moral diasumsikan melekat dalam setiap materi yang dipilih. Hal ini disebabkan IFRS memberi peluang lebih besar bagi judgement pelaku akuntansi. Semangat pengajaran di setiap matakuliah harus ditetapkan secara berbeda agar tidak tumpang tindih. Para akademisi juga seharusnya mengkritisi standar akuntansi yang berlaku agar mahasiswa tidak hanya bisa memanfaatkan standar tanpa punya prinsip. Lebih lanjut, metode pengajaran materi IFRS harus disesuaikan dengan kompetensi yang ingin dicapai.

Masalah yang kerap muncul dalam ranah pendidikan akuntansi adalah terbatasnya bahan ajar (buku teks), waktu pengajaran, dan kemampuan dosen (Cherubini dkk, 2011 dalam Suhardianto (2011)). Buku teks edisi IFRS saat ini sudah bisa diperoleh baik untuk level PA, AKM, maupun AKL meskipun para pengajar harus beradaptasi dengan buku baru. Selain itu, sumber-sumber bacaan online bisa diperoleh daari situs-situs KAP internasional maupun situs IASB (Holtzblatt dan Tschakert, 2010 dalam Suhardianto (2011)). Untuk mengatasi terbatasnya waktu pengajaran, para pengajar bisa 
menggunakan waktu asistensi atau tutorial dan tentunya sangat bergantung pada keaktifan mahasiswa. PT dan para dosen secara pribadi bertangggungjawab terhadap penguasaan materi IFRS. Meskipun akademisi boleh saja menolak IFRS, pemahaman terhadap IFRS mutlak diperlukan sebelum menentukan sikap yang objektif dan proporsional. Di sisi lain, SAK Syariah dan SAK ETAP juga merupakan standar akuntansi yang patut direspon secara proporsional dalam area pendidikan akuntansi (Suhardianto, 2011)

\section{METODE}

Jenis penelitian yang digunakan adalah kualitatif dengan menggunakan latar alamiah yang bertujuan menafsirkan fenomena yang terjadi. Metode yang digunakan terdiri atas tahap analisis serta deskripsi dan hasil akhirnya berupa deskripsi fenomenologis. Selain itu, dalam penelitian ini juga menginginkan diperolehnya suatu hasil yang lebih mendekati kenyataan. Dan karena peneliti juga memiliki akses masuk ke dalam obyek penelitian. Peneliti sebagai alat (instrumen) penelitian (Moleong, 2010:51).

Penelitian ini fokus untuk menggali informasi dan memahami pendapat informan atas kesiapan dan pelaksanaan perkuliahan berbasis konvergensi IFRS di Perguruan Tinggi Swasta. Kesiapan yang dimaksud adalah kesiapan program studi akuntansi dan dosennya untuk menerapkan perkuliahan akuntansi berbasis konvergensi IFRS. Untuk pelaksanaannya yang dimaksud adalah proses pelaksanaan perkuliahan yang berbasis konvergensi IFRS di dua PTS yang telah ditentukan.

Unit analisis penelitian ini adalah pendapat informan kunci yang terdiri dari ketua program studi akuntansi Universitas "X" Sidoarjo dan STIE "Y" Surabaya, perwakilan dosen dan pengamat konvergensi IFRS. Pendapat yang diteliti adalah kesiapan dan pelaksanaan perkuliahan akuntansi berbasis konvergensi IFRS. Penggunaan unit analisis seperti ini memang sesuai dengan pendapat Basuki (2011) bahwa unit analisis berhubungan dengan "apa yang diteliti”. Dengan menggunakan unit analisis seperti ini maka tujuan penelitian yakni untuk memahami kesiapan dan pelaksanaan perkuliahan akuntansi berbasis konvergensi IFRS di PTS dapat lebih mudah untuk dicapai. 
Informan kunci dalam penelitian ini adalah ketua program studi akuntansi Universitas "X" Sidoarjo dan STIE "Y" Surabaya, perwakilan dosen akuntansi, akuntan atau pengamat konvergensi IFRS. Berikut informan kunci pada penelitian ini :

Tabel 1. Data Informan Kunci

\begin{tabular}{cll}
\hline No & \multicolumn{1}{c}{ Nama } & \multicolumn{1}{c}{ Keterangan } \\
\hline 1 & IDR & Kaprodi Akuntansi Universitas "X" Sidoarjo \\
\hline 2 & SRD & Dosen Akuntansi Pengantar Universitas "X" Sidoarjo \\
\hline 3 & HW & Dosen Akt Keu Menengah Universitas "X" Sidoarjo \\
\hline 4 & NA & Dosen Akt Keu Lanjutan Universitas "X" Sidoarjo \\
\hline 5 & PD & Sekretaris Prodi Akuntansi STIE "Y" Surabaya \\
\hline 6 & GH & Dosen Akuntansi Pengantar STIE "Y" Surabaya \\
\hline 7 & NHD & Dosen Akuntansi Keuangan STIE "Y" Surabaya \\
\hline 8 & NS & Dosen Akuntansi Keu Lanjutan STIE "Y" Surabaya \\
\hline 9 & BO & Akuntan dan pemerhati konvergensi IFRS \\
\hline
\end{tabular}

Sumber : Data In Depth Interview

Penentuan informan kunci dalam penelitian ini dilakukan dengan penetapan oleh peneliti (judgment) dan sampling bola salju (snowball sampling) (Marshall, 1996). Untuk informan kunci yang ditetapkan dengan judgment, yakni informan IDR, SRD, HW, NA, GH, NHD, NS dan B. Untuk informan kunci yang ditetapkan ketika proses penelitian berlangsung atau dengan snowball sampling adalah informan PD. Penggunaan informan hasil snowball sampling tersebut disamping karena rekomendasi dari para informan yang sudah ditetapkan di awal, juga karena kebutuhan informasi yang diperlukan oleh peneliti.

Data dalam penelitian ini dikumpulkan melalui tiga cara, yakni in depth interview, observasi, dan dokumentasi (Marshall, 2006). Proses pengumpulan data dilakukan mulai Maret - Juli 2012. In depth interview dilakukan dengan wawancara tak terstruktur. Metode ini digunakan untuk mendapatkan informasi tentang kesiapan dan pelaksanaan perkuliahan akuntansi konvergensi IFRS di Perguruan Tinggi Swasta melalui informan kunci yang telah ditentukan sebelumnya. Untuk menunjang wawancara tak terstruktur tersebut, peneliti menggunakan pedoman wawancara dan tape recorder. Sementara itu, observasi dilakukan dengan pengamatan langsung yakni perkuliahan akuntansi yang diselenggarakan oleh program studi akuntansi Universitas "X" Sidoarjo dan program studi akuntansi STIE "Y" Surabaya. Cara terakhir adalah pendokumentasian yang dilakukan dengan mencari data, misalnya silabus mata kuliah, jurnal perkuliahan, dan kurikulum akuntansi. 
Proses analisis data dalam penelitian ini dilakukan dengan cara merekam data lapangan, melakukan pengecekan anggota pada subyek penelitian. Pada penelitian ini juga dilakukan triangulation test sebagai upaya keabsahan data (Senton, 2004). yang pernah dilakukan oleh Hermawan (2011:250) yaitu untuk memperoleh keabsahan data dan menyempurnakan analisis. Triangulation Test ini dilakukan dengan cara hasil dokumentasi atas kesiapan dan pelaksanaan konvergensi IFRS akan ditriangulasikan dengan observasi dan wawancara kepada pihak-pihak yang berkepentingan langsung yang ada di Universitas "X" Sidoarjo dan STIE "Y" Surabaya. Demikian pula dengan hasil wawancara akan di cross check dengan data dari hasil dokumentasi dan observasi. Pemeriksaan keabsahan data dapat pula dilakukan dengan pengecekan anggota (Moleong, 2010:181).

Sementara itu, analisis data dalam penelitian ini dilakukan selama tahapan proses pengumpulan data (Miles and Huberman, 1984). Analisis data juga dilakukan secara interaktif dan dilakukan secara terus menerus selama proses dan sampai tuntas penelitian sehingga situasi atau konteks dalam suatu fenomena tidak tertinggal dalam analisis. Aktivitas analisis data selama proses pengumpulan data meliputi data collection, data reduction, data display, dan conclusion : drawing / verifying. Analisis data seperti ini pernah dilakukan oleh Hermawan (2011:252).

\section{HASIL PENELITIAN DAN PEMBAHASAN}

Tahapan untuk memperoleh keabsahan data dalam análisis penelitian yakni dengan menggunakan triangulasi data dimana data diperoleh dari hasil dokumentasi yang ditriangulasikan dengan observasi dan wawancara pada responden yang berkepentingan langsung. Data tanggapan dari informan kunci akan di crosscheck dengan hasil dokumentasi dan observasi serta teori. Berikut disajikan data dokumentasi dan observasi:

Tabel 2

Data Dokumentasi dan Observasi

\begin{tabular}{clc}
\hline No & \multicolumn{1}{c}{ Keterangan } & \multicolumn{1}{c}{ Sumber } \\
\hline 1 & $\begin{array}{l}\text { Struktur Organisasi Univeristas "X" } \\
\text { Sidoarjo }\end{array}$ & Buku Panduan Akademik \\
\hline 2 & $\begin{array}{l}\text { Gambaran Umum Universitas "X" } \\
\text { Sidoarjo }\end{array}$ & Buku Panduan Akademik \\
\hline 3 & $\begin{array}{l}\text { Kurikulum Prodi Akuntansi Univ "X" } \\
\text { Sidoarjo }\end{array}$ & Buku Panduan Akademik \\
\hline
\end{tabular}




\begin{tabular}{cll}
\hline 4 & Silabi Matakuliah Akuntansi Pengantar & FE Univ "X" Sidoarjo \\
\hline 5 & Silabi Matakuliah Akt Keu Menengah & FE Univ "X" Sidoarjo \\
\hline 6 & Silabi Matakuliah Akt Keu Lanjutan & FE Univ "X" Sidoarjo \\
\hline 7 & Jurnal Perkuliahan MK Akt Pengantar & FE Univ "X" Sidoarjo \\
\hline 8 & $\begin{array}{l}\text { Jurnal Perkuliahan MK Akt Keuangan } \\
\text { Menengah }\end{array}$ & FE Univ "X" Sidoarjo \\
\hline 9 & $\begin{array}{l}\text { Jurnal Perkuliahan MK Akt Keuangan } \\
\text { Lanjutan }\end{array}$ & FE Univ "X" Sidoarjo \\
\hline 10 & Struktur Organisasi STIE "Y" Surabaya & Web STIE "Y" Surabaya \\
\hline 11 & Gambaran Umum STIE "Y" Surabaya & Web STIE "Y" Surabaya \\
\hline 12 & Kurikulum Prodi Akuntansi STIE "Y" & Web STIE "Y" Surabaya \\
& Surabaya & \\
\hline 13 & Silabi matakuliah Akt Pengantar & Web STIE "Y" Surabaya \\
\hline 14 & Silabi matakuliah Akt Keu Menengah & Web STIE "Y" Surabaya \\
\hline 15 & Silabi matakuliah Akt Keu Lanjutan & Web STIE "Y" Surabaya \\
\hline
\end{tabular}

Sumber : Data Dokumentasi dan Observasi

Berdasarkan data-data yang telah diperoleh dan telah ditriangulasi, berikut pembahasan kesiapan dan pelaksanaan perkuliahan akuntansi berbasis IFRS di Universitas " $X$ " Sidoarjo dan STIE "Y” Surabaya.

\section{Kesiapan Prodi Akuntansi Universitas " $X$ " Sidoarjo dan STIE "Y" Surabaya dalam menghadapi konvergensi IFRS}

Universitas "X" Sidoarjo dan STIE "Y" Surabaya telah melakukan berbagai upaya kesiapan dalam menerapkan perkuliahan berbasis konvergensi IFRS, upaya kesiapan tersebut meliputi:

\section{a. Kesiapan Prodi Akuntansi}

Tanggapan pertama diberikan oleh IDR, SE.Ak, M.Ak selaku Ketua Prodi Akuntansi Universitas " $\mathrm{X}$ " Sidoarjo yang menyatakan bahwa mengenai konvergensi IFRS yang dilihat dari sosialisasi dari IFRS yang akan mulai dilaksanakan tahun 2012. Beliau menyatakan kalau Prodi Akuntansi harus mengikuti tren untuk menggunakan IFRS, dengan tahap awal kesiapan dari Sumber Daya Manusia (dosen) yang sudah menggunakan buku-buku yang berbasis IFRS. Untuk kajian mendalam tentang IFRS belum dilakukan karena untuk penerapan IFRS tidak mudah, karena pedoman atau standartnya yang diubah. Upaya yang dilakukan Prodi Akuntansi pada tahap awal dengan mengirimkan beberapa dosen untuk mengikuti pelatihan IFRS dan menyelenggarakan seminar tentang konvergensi IFRS untuk dosen-dosen 
pengajar akuntansi, dengan meminta dukungan dari pihak Universitas dalam hal pendanaan. Berikut komentarnya:

"Kalau kita lihat kesiapannya, kita lihat dulu sosialisasi dari IFRS yang akan mulai dilaksanakan pada tahun ini, tahun 2012. Nah kalau prodi akuntansi itu memang harus mengikuti tren untuk menggunakan IFRS. Cuma sekarang untuk tahap awal itu banyak teman-teman dosen yang sudah menggunakan buku-buku yang berbasis IFRS juga. Cuma untuk kajian mendalam tentang IFRS itu belum kita lakukan, tapi ini kita masih proses ke teman-teman dosen." (Petikan wawancara dengan IDR, SE.Ak, M.Ak Ketua Prodi Akuntansi Universitas " $X$ " Sidoarjo pada tanggal 12 Juni 2012).

Hal ini memang sesuai dengan hasil trianggulasi data yang dilakukan oleh peneliti dengan membandingkan hasil wawancara dengan dokumentasi dan observasi berupa pelaksanaan diskusi ilmiah untuk dosen-dosen akuntansi dengan judul "Konvergensi SAK ETAP dan IFRS ke dalam Kurikulum Prodi Akuntansi” yang juga diikuti oleh peneliti pada tanggal 18 Juli 2012 di Fakultas Ekonomi UMSIDA. Serta tentang dosen yang telah menggunakan buku-buku berbasis IFRS ditriangulasi dengan data dokumentasi berupa Silabi Matakuliah AKL II yang diperoleh dari staf FE Universitas "X" Sidoarjo. Berdasarkan hasil triangulasi data menyimpulkan bahwa Prodi Akuntansi Universitas " $X$ " Sidoarjo telah menyelenggarakan seminar tentang konvergensi IFRS dan untuk beberapa dosen juga telah menggunakan buku-buku ajar berbasis IFRS.

Tanggapan kedua diberikan oleh PD, SE.Ak, M.Si selaku Sekretaris Prodi Akuntansi STIE "Y" Surabaya yang menyatakan berbeda, bahwa di STIE "Y" Surabaya sudah menerapkan IFRS pada matakuliah Akuntansi Keuangan I dan Akuntansi Keuangan II. Dosen-dosen di STIE "Y" Surabaya sudah ada yang membuat buku untuk diperkenalkan di mahasiswa. Selain itu, menurut beliau buku wajib bagi mahasiswa sudah ada yang memakai konvergensi IFRS, khususnya untuk mata kuliah Akutansi Keuangan. Upaya yang dilakukan Prodi Akuntansi STIE "Y" Surabaya adalah dengan mengikutkan dosen untuk seminar, pelatihan untuk update materi IFRS. Berikut komentarnya:

"Kalau di STIE ini, kita sudah apply IFRS pada matakuliah Akuntansi Keuangan 1 dan Akuntansi Keuangan 2. Dosen kita sudah ada yang membuat buku itu. Selain itu buku wajibnya sudah ada yg pakai konvergensi IFRS, untuk matakuliah yang ranahnya Akuntansi Keuangan." (Petikan wawancara dengan PD SE.Ak, M.Si. Sekretaris Prodi Akuntansi STIE "Y" Surabaya pada tanggal 2 Juli 2012). 
Hal ini sesuai dengan hasil wawancara dengan Dosen Akutansi Keuangan STIE "Y" Surabaya, NHUD, SE, M.Si. berikut komentarnya:

"Kesiapan mau tidak mau sudah kita persiapkan, kalau misalkan kita nanti harus konvergensi 2012 maka kita juga sudah mempersiapkan. Jadi sudah mulai dari 20102011 kita sudah menyiapkan modul yg anak-anak mahasiswa bisa memahami IFRS sekaligus tidak lepas dari PSAK yang kita gunakan yang sudah adaptasi ke IFRS. Kita sudah siapkan untuk matakuliah IntermediateI dan Intermediate II." (Petikan wawancara dengan NHUD SE, M.Si. Dosen Pengampu Matakuliah Akuntansi Keuangan II STIE “Y” Surabaya pada tanggal 2 Juli 2012).

Berdasarkan hasil triangulasi data menyimpulkan bahwa Prodi Akuntansi STIE "Y" Surabaya sudah benar-benar menyiapkan modul untuk matakuliah IntermediateI dan Intermediate II yang berbasis konvergensi IFRS. Demikian juga dengan matakuliah Akuntansi Keuangan I dan Akuntansi Keuangan II. Dengan melihat hal yang demikian, dapat disimpulkan bahwa Prodi Akuntansi STIE "Y" Surabaya sudah siap menerapkan matakuliah konvergensi IFRS. Namun sebaliknya, Prodi Akuntansi Universitas " $X$ " Sidoarjo belum siap menerapkan perkuliahan berbasis konvergensi IFRS.

\section{b. Kesiapan Akademisi}

Tanggapan pertama diberikan oleh SRD, SE, M.Si sebagai Dosen Pengampu Matakuliah Akuntansi Pengantar yang menyatakan bahwa di Universitas " $\mathrm{X}$ " Sidoarjo rata-rata belum siap menerapkan perkuliahan berbasis konvergensi IFRS. Beliau berpendapat kalau SAK ETAP sebenarnya masih sama dengan yang lama, tapi kalau IFRS harus ada pelatihan lebih dulu. Karena masih banyak dosen yang belum mengetahui secara persisnya perbedaan sebelum dan setelah IFRS. Berikut komentarnya:

"Kalau yang disini... rata-rata belum, karena memang seharusnya untuk IFRS sendiri ini ada pelatihan khusus karena ada banyak sekali perbedaan dengan yang sudah ada. Mungkin kalau ETAP kita tinggal sedikit saja mengetahui bagian-bagian mana yangsebenarnya masih sama dengan yang lama, tapi kalau IFRS harus ada pelatihan lebih dulu. Saya kira belum." (Petikan wawancara dengan SRD, SE, M.Si, Dosen Pengampu Matakuliah Akuntansi Pengantar II Universitas " $X$ " Sidoarjo pada tanggal 9 Juni 2012). 
Hal ini sesuai dengan hasil trianggulasi data yang dilakukan oleh peneliti dengan membandingkan hasil wawancara dengan dokumentasi berupa Jurnal Kegiatan Matakuliah AP II yang diperoleh dari staf FE Universitas "X" Sidoarjo. Berdasarkan hasil triangulasi data menyimpulkan bahwa dosen AP II Universitas " $\mathrm{X}$ " Sidoarjo belum siap menerapkan perkuliahan berbasis konvergensi IFRS.

Sama halnya dengan tanggapan dari Dra. GH, Ak, M.Si. sebagai Dosen Pengampu Matakuliah Akuntansi Pengantar di STIE "Y" Surabaya bahwa untuk matakuliah Akuntansi Pengantar I dan II belum mengunakan IFRS, masih update ke SAK ETAP. Hal ini memang sesuai dengan hasil trianggulasi data yang dilakukan oleh peneliti dengan membandingkan hasil wawancara dengan dokumentasi berupa Silabi Matakuliah AP II yang diperoleh dari web STIE "X" Surabaya. Berdasarkan hasil triangulasi data menyimpulkan bahwa dosen AP II STIE "Y" Surabaya sedang proses update ke SAK ETAP, belum menggunakan IFRS.

Tanggapan yang sama diberikan oleh HW, SE, M.Si sebagai Dosen Pengampu Matakuliah AKM yang menyatakan bahwa di Universitas " $X$ " Sidoarjo masih proses perubahan ke SAK ETAP. Karena menurut beliau antara perusahaan yang sudah dan belum menerapkan IFRS, masih banyak yang belum menggunakannya. Jadi kesimpulannya beliau tidak langsung ke IFRS, tetapi melalui SAK ETAP lebih dahulu. Berikut komentarnya:

"Kalau dari sisi akademisi, mau tidak mau yah harus mempelajari. Dari satu sisi agak dilema, kalau hanya langsung mempelajari IFRS tanpa mempelajari ETAP. Kasihan juga mahasiswa... saya mikirnya kalau perusahaan yang pakai IFRS harusnya yang sudah entitas publik, punya tanggung jawab terhadap publik. Bandingkan dengan perusahaan yang boleh tidak menggunakan IFRS. (Petikan wawancara dengan HW, SE, M.Si, Dosen Pengampu Matakuliah AKM II Universitas "X" Sidoarjo pada tanggal 13 Juni 2012).

Hal ini memang sesuai dengan hasil trianggulasi data yang dilakukan oleh peneliti dengan membandingkan hasil wawancara dengan dokumentasi berupa Silabi Matakuliah AKM II yang diperoleh dari staf FE Universitas "X" Sidoarjo. Berdasarkan hasil triangulasi data disimpulkan bahwa untuk matakuliah AKM II di Universitas "X" Sidoarjo belum siap menerapkan perkuliahan berbasis konvergensi IFRS, tetapi masih fokus pada SAK ETAP. 
Tabel 3.

Kesiapan Akademisi Universitas "X" dan STIE "Y" Surabaya

\begin{tabular}{|c|c|c|c|}
\hline No & Dosen & Matakuliah & Kesiapan \\
\hline & \multicolumn{3}{|c|}{ Universitas "X" Sidoarjo } \\
\hline 1 & SRD & Akuntansi Pengantar II & Belum Siap \\
\hline 2 & HW & Akt Keuangan Menengah II & Belum Siap \\
\hline 3 & NA & Akt Keuangan Lanjutan II & Siap \\
\hline \multicolumn{4}{|c|}{ STIE "Y" Surabaya } \\
\hline 1 & GH & Akuntansi Pengantar II & Belum Siap \\
\hline 2 & NHUD & Akuntansi Keuangan Menengah II & Siap \\
\hline 3 & NS & Akuntansi Keuangan Lanjutan II & \\
\hline
\end{tabular}

Upaya kesiapan yang telah dilakukan oleh para Akademisi di Universitas " $\mathrm{X}$ " Sidoarjo dan STIE "Y" Surabaya adalah sebagai berikut:

1) mengikuti berbagai pelatihan dan seminar tentang IFRS,

2) mengikuti sosialisasi tentang IFRS,

3) browsing dari internet untuk Update Materi IFRS,

4) belajar dari Dosen (yang kebetulan kuliah S2 atau Profesi).

Berdasarkan hasil penelitian dapat disimpulkan bahwa akademisi Akuntansi Universitas "X" Sidoarjo yang belum siap menerapkan perkuliahan berbasis konvergensi IFRS adalah matakuliah Akuntansi Pengantar II dan Akuntansi Keuangan Menengah II. Sementara itu, untuk akademisi Akuntansi STIE "Y" Surabaya yang telah benar-benar siap adalah dosen untuk matakuliah Akuntansi Pengantar II.

Apabila dikaitkan dengan teori tentang kesiapan (Slameto, 2003) dapat diketahui memang prodi dan dosen akuntansi STIE "Y" telah siap untuk melakukan perkuliahan berbasis konvergensi IFRS. Hal tersebut dapat dilihat dari keseluruhan kondisi seseorang (prodi dan dosen) untuk memberikan respon atau jawaban dalam kondisi tertentu terhadap suatu situasi dalam hal ini perkembangan IFRS. Hal sebaliknya terjadi pada prodi dan dosen Akuntansi Universitas "X" Sidoarjo yang belum siap untuk melakukan perkuliahan berbasis IFRS. Hal tersebut dapat dilihat dari kematangan dalam memberikan respon atas konvergensi IFRS. Tentang prodi dan dosen Akuntansi Universitas " $X$ " Sidoarjo yang belum siap melakukan perkuliahan konvergensi IFRS sejalan dengan hasil penelitian Widiastuti (2011) yang menyatakan bahwa kesiapan dosen akuntansi untuk mengintegrasikan materi IFRS 
dalam perkuliahan masih relatif rendah. Demikian pula dengan kesiapan prodi untuk memfasilitasi dosen memberikan perkuliahan konvergensi IFRS masih sangatlah rendah.

\section{Pelaksanaan perkuliahan yang berbasis konvergensi IFRS di Prodi Akuntansi}

\section{Universitas "X" Sidoarjo dan STIE "X" Surabaya}

Pelaksanaan perkuliahan akuntansi berbasis konvergensi IFRS memerlukan Sumber Daya Manusia (Dosen) yang sudah mengerti dan paham harmonisasi dari PSAK ke IFRS khususnya untuk matakuliah Akuntansi Pengantar, Akuntansi Keuangan Menengah, Akuntansi Keuangan Lanjutan, Auditing dan Teori Akuntansi. Pada penelitian ini wawancara hanya dilakukan dengan akademisi Akuntansi Pengantar, Akuntansi Keuangan Menengah, dan Akuntansi Keuangan Lanjutan. Hal ini sudah cukup representatif mewakili matakuliah yang lain.

Tanggapan pertama diberikan oleh NHUD, SE, M.Si sebagai Dosen Pengampu Matakuliah Akuntansi Keuangan di STIE "Y" Surabaya bahwa untuk matakuliah Intermediate I dan Intermediate II sudah sedikit banyak akun-akun yang dijelaskan itu sudah adopsi dari IFRS. Bahkan mulai dari persiapan untuk memahami IFRS dalam konteks pembelajaran, memahami IFRS untuk penerapan di perusahaan. Sudah diikuti semua, sebelum akhirnya bisa membuat modul yang bisa digunakan internal. Untuk pelaksanaan perkuliahan di STIE "Y" Surabaya yang menjadi kendala adalah buku yang basisnya konvergensi IFRS rata-rata masih menggunakan bahasa asing. Berikut komentarnya:

"Kalau pertama sebenarnya ketika konvergensi IFRS kita memang mengadopsi pakai buku yang basisnya bahasa asing. Kalau yang GAAP dulu itu kan karena sudah lama kita menerapkan, jadi banyak terjemahannya bisa mereka mempermudah. Karena itu masih baru, jadi belum banyak terjemahan IFRS. Salah satunya adalah selain mereka buku wajibnya adalah buku wajib yang dari pengarang luar, kita ada buku wajib yang berupa modul untuk membantu memahami. Akuntansi Keuangan adaptasi PSAK, SAK ETAP, dan IFRS.(Petikan wawancara dengan NHUD SE, M.Si. Dosen Pengampu Matakuliah Akuntansi Keuangan II STIE "Y" Surabaya pada tanggal 2 Juli 2012).

Hal itu sesuai dengan hasil trianggulasi data yang dilakukan oleh peneliti dengan membandingkan hasil wawancara dengan dokumentasi berupa Silabi Matakuliah AK II yang diperoleh dari web STIE "X" Surabaya. Berdasarkan hasil triangulasi data 
menyimpulkan bahwa untuk matakuliah AKM II di STIE "X" Surabaya memang sudah melakasanakan perkuliahan berbasis konveregnsi IFRS.

Tanggapan selanjutnya diberikan oleh NA, SE., M.SA., Ak, sebagai Dosen Pengampu Matakuliah Akuntansi Keuangan Lanjutan yang menyatakan bahwa di Universitas "X" Sidoarjo yang beliau ajarkan sudah memakai IFRS. Karena kebetulan beliau pada saat itu sedang menempuh kuliah S2 di STESIA, jadi sedikit banyak pelajaran yang diperoleh sudah menerapkan IFRS. Untuk pelaksanaannya dalam perkuliahaan, beliau menyatakan bahwa yang menjadi kendala adalah tidak adanya literatur yang mendukung. Kalaupun ada masih menggunakan bahasa asing dan bahasa peraturan, bukan bahasa buku,jadi aplikasinya masihsulit untuk dipahami. Beliau menyarankan sebagai bahan tambahan dapat browsing dariinternet, karena di internet selalu diupdate.Berikut komentarnya:

"Kalau yang saya ajarkan sudah pakai IFRS. Saya kebetulan kuliah S2 di STESIA. Jadi yang saya dapat yah saya terapkan ke mahasiswa. Karena saya sudah dapat, tapi tidak tahu yang lain yang tidak kebetulan sekolah seperti saya. Kalau proses pelaksanaanya yang menjadi kendala mahasiswa yah pasti kebanyakan mengeluhnya yah karena tidak ada literatur itu satu-satunya... tidak adanya literatur yang mendukung. Kalaupun ada masih menggunakan bahasa asing yang sulit dipahami

(Petikan wawancara dengan NA SE,Ak, Dosen Pengampu Matakuliah Akuntansi Keuangan Lanjutan II Universitas " $X$ " Sidoarjo pada tanggal 9 Juni 2012)

Hal itu sesuai dengan hasil trianggulasi data yang dilakukan oleh peneliti dengan membandingkan hasil wawancara dengan dokumentasi berupa Silabi Matakuliah AKL II yang diperoleh dari staf FE Universitas " $\mathrm{X}$ " Sidoarjo. Berdasarkan hasil triangulasi data dapat disimpulkan bahwa untuk matakuliah AKL II di Universitas " $\mathrm{X}$ " Sidoarjo memang sudah melaksanakan perkuliahan berbasis konveregnsi IFRS.

Tanggapan selanjutnya dari NS, SE.Ak, M.Si selaku Dosen Pengampu Matakuliah Akuntansi Keuangan Lanjutan di STIE "Y" Surabaya yang menyatakan bahwa beliau sudah mengajarkan bagaimana cara mengkonvergensikan, mengharmonisasikan atau meng-adjustment dari PSAK ke IFRS. Untuk proses pelaksanaannya beliau hanya memberikan dasar-dasar terkait dengan pemahaman IAS dan IFRS, jadi diberitahukan dahulu bagaimana perubahannya, sebelum dan setelah perubahan dan perubahnnya dalam hal apa saja. Berikut komentarnya: 
"Kalau di matakuliah Akuntansi Internasional itu sudah, sudah diajarkan bagaimana cara mengkonvergensi, mengharmonisasi atau meng-adjustment dari PSAK ke IFRS. Terus kemudian kaitannya dengan pola pendidikan yang diajarakan di kelas itu bagaimana, selama ini mahasiswa itu hanya diberikan dasar-dasar terkait dengan pemahaman IAS dan IFRS itu sendiri." (Petikan wawancara dengan NS, SE.Ak, M.Si Dosen Pengampu Matakuliah Akuntansi Keuangan Lanjutan II STIE "Y" Surabaya pada tanggal 2 Juli 2012).

Hal itu sesuai dengan hasil trianggulasi data yang dilakukan oleh peneliti dengan membandingkan hasil wawancara dengan dokumentasi berupa Silabi Matakuliah AKL II yang diperoleh dari web STIE "Y" Surabaya. Berdasarkan hasil triangulasi data dapat disimpulkan bahwa untuk matakuliah AKL II di STIE "Y" Surabaya memang sudah melakasanakan perkuliahan berbasis konveregnsi IFRS.

Tabel 4.

PelaksanaanPerkuliahan Universitas " $X$ " Sidoarjo dan STIE "Y" Surabaya

\begin{tabular}{llll}
\hline No & \multicolumn{1}{c}{ Dosen } & \multicolumn{1}{c}{ Matakuliah } & Pelaksanaan \\
\hline & Universitas "X" & \\
\hline 1 & SRD & Akuntansi Pengantar II & Belum \\
\hline 2 & HW & Akuntansi Keuangan Menengah II & Belum \\
\hline 3 & NA & Akuntansi Keuangan Lanjutan II & Sudah \\
\hline & STIE "Y" Surabaya & \\
\hline 1 & GH & Akuntansi Pengantar II & Belum \\
\hline 2 & NHUD & Akuntansi Keuangan Menengah II & Sudah \\
\hline 3 & NS & Akuntansi Keuangan Lanjutan II & Sudah \\
\hline
\end{tabular}

Sumber : Data Diolah

Berdasarkan hasil penelitian dapat disimpulkan bahwa akademisi Akuntansi Universitas " $\mathrm{X}$ " Sidoarjo yang sudah melaksanakan perkuliahan berbasis konvergensi IFRS adalah dosen untuk matakuliah Akuntansi Keuangan Lanjutan II. Sementara itu, untuk akademisi STIE "Y" Surabaya yang sudah melaksanakan perkuliahan perkuliahan berbasis konvergensi IFRS adalah dosen untuk matakuliah Akuntansi Keuangan II dan Akuntansi Keuangan Lanjutan II.

Berkaitan dengan hasil penelitian ini yang menyatakan bahwa perkuliahan berbasis konvergensi IFRS yang sudah dilakukan oleh dosen prodi Akuntansi Universitas "X" Sidoarjo dan STIE "Y" Surabaya adalah untuk matakuliah Akuntansi Keuangan II dan Akuntansi Keuangan Lanjutan II. Hal ini masih sangat kurang apabila dikaitkan dengan rekomendasi hasil penelitian Suhardianto (2011), yang menyatakan bahwa untuk jenjang pendidikan S1 Akuntansi, matakuliah yang 
terkait dengan konvergensi IFRS adalah Akuntansi Pengantar, Akuntansi Keuangan Menengah, Akuntansi Keuangan Lanjutan, Auditing, dan Teori Akuntansi. Dengan melihat hal yang demikian, masih sangat banyak perkuliahan yang belum dilaksanakan dengan konvergensi IFRS.

\section{Tanggapan Konsultan atau Pemerhati Konvergensi IFRS}

Untuk dapat memberi masukan tentang upaya mempersiapkan perkuliahan akuntansi berbasis konvergensi IFRS, peneliti melakukan in depth interview dengan pemerhati konvergensi IFRS sekaligus juga sebagai akuntan senior di Kantor Akuntan Publik (KAP) Abdulrahman Hasan Salipu, Ak, yakni Bapak B, SE., M.Ak., Ak. Menurut beliau, bahwa upaya kesiapan yang dilakukan oleh Perguruan Tinggi sudah cukup bagus, tetapi perlu adanya persiapan yang lebih matang dan lebih ditingkatkan lagi agar dalam pelaksanaannya dapat berjalan dengan baik. Upaya dalam menunjang kesiapan dalam konvergensi IFRS, dosen - dosen akuntansi seharusnya sering mengikuti seminar - seminar maupun menambah literatur buku penunjang IFRS, melakukan diskusi-diskusi ilmiah dengan mengajak pihak ketiga dalam hal ini praktisi baik akuntan publik, penilai publik, perbankan dan lainnya. Berikut komentarnya:

"Upaya dalam menunjang kesiapan konvergensi IFRS, dosen - dosen akuntansi harusnya sering ikut seminar - seminar maupun menambah literatur buku penunjang IFRS, melakukan diskusi-diskusi ilmiah dengan mengajak pihak ketiga dalam hal ini praktisi baik akuntan publik, penilai publik, perbankan dan lain-lain." (Petikan wawancara dengan B, S.E.,M.Ak.,Ak, Pemerhati Konvergensi IFRS dan Akuntan Senior pada tanggal 27 Juli 2012).

Akan tetapi menurut beliau ada beberapa hal yang perlu diperhatikan untuk proses perkuliahan akuntansi yang berbasis konvergensi IFRS, yaitu sebagai berikut:

a. Sebelum membuat kurikulum, perlu dibuat skala prioritas berapa persen yang akan mengarah ke Standar Akuntansi Keuangan Entitas Tanpa Akuntabilitas Publik (SAK-ETAP) dan Non SAK-ETAP, baru ke penyusunan kurikulumnya.

b. Kurikulum dengan memodifikasi GBPP yang sudah dihasilkan dalam Semiloka Nasional Kurikulum S1 Akuntansi Mengacu Kerangka Kualifikasi Nasional Indonesia (KKNI) dengan silabus yang sudah ada di program studi serta ditambahkan prosedur pembelajaran dengan Model Student Centered Learning $(S C L)$. 
c. Diadakan perkuliahan umum dengan mendatangkan pihak ketiga (praktisi) yang terkait dengan bidang akuntansi, baik akuntan publik, akuntan manajemen, akuntan sektor dan lain-lain.

d. Sarana prasarana khususnya literatur-literatur yang baru perlu lebih dilengkapi.

e. Melakukan kerjasama dengan pihak ketiga dalam hal magang kerja.

\section{SIMPULAN DAN SARAN}

Berdasarkan hasil penelitian dapat disimpulkan bahwa Prodi Akuntansi Universitas " $\mathrm{X}$ " Sidoarjo belum siap menerapkan perkuliahan akuntansi berbasis konvergensi IFRS. Pada saat ini masih dalam proses mempersiapkan kurikulum baru yang berbasis konvergensi IFRS. Sementara itu, Prodi Akuntansi STIE "X" Surabaya sudah siap menerapkan perkuliahan berbasis konvergensi IFRS pada beberapa matakuliah tertentu. Untuk kesiapan akademisi dapat disimpulkan bahwa akademisi Akuntansi Universitas " $\mathrm{X}$ " Sidoarjo yang belum siap menerapkan perkuliahan berbasis konvergensi IFRS adalah akademisi untuk matakuliah Akuntansi Pengantar II dan Akuntansi Keuangan Menengah II. Sedangkan akademisi Akuntansi STIE "Y" Surabaya yang belum siap menerapkan perkuliahan berbasis konvergensi IFRS adalah akademisi untuk matakuliah Akuntansi Pengantar II.

Untuk pelaksanaan perkuliahan akuntansi berbasis konvergensi IFRS disimpulkan bahwa akademisi Akuntansi Universitas " $X$ " Sidoarjo yang sudah melaksanakan perkuliahan akuntansi berbasis konvergensi IFRS adalah matakuliah Akuntansi Keuangan Lanjutan II. Sementara itu, untuk STIE "X" Surabaya yang sudah melaksanakan perkuliahan akuntansi berbasis konvergensi IFRS adalah matakuliah Akuntansi Keuangan II dan Akuntansi Keuangan Lanjutan II.

Saran untuk Prodi Akuntansi Universitas "X" Sidoarjo adalah bahwa untuk kesiapan dan pelaksanaan yang telah dilakukan agar lebih dipersiapkan dan ditingkatkan lagi supaya perkuliahan akuntansi berbasis konvergensi IFRS bisa segera diterapkan dan dilaksanakan dengan baik sehingga dapat meningkatkan kompetensi lulusan prodi akuntansi Universitas "X" Sidoarjo di masa mendatang. Saran untuk Prodi Akuntansi STIE "Y" Surabaya bahwa perkuliahan akuntansi berbasis IFRS yang telah ada harus tetap dipertahankan dan dikembangkan pada matakuliah lain yang relevan. Saran secara umum untuk prodi akuntansi adalah pemetaan profil lulusan sebelum melakukan 
penyusunan kurikulum konvergensi IFRS. Maksudnya adalah profil lulusan lebih banyak diserap oleh pasar tenaga kerja yang mana?Apakah pada level perusahaan multi nasional atau hanya pada perusahaan level nasional atau level UMKM. Kalau lulusan banyak terserap di perusahaan multi nasional maka kurikulum yang menitik beratkan pada konvergensi IFRS dapat dilakukan. Namun apabila lulusan banyak terserap di perusahaan nasional atau UMKM maka kurikulum lebih baik dititikberatkan pada SAK ETAP. Saran untuk peneliti yang akan datang adalah sebaiknya memilih lima matakuliah inti akuntansi agar mendapatkan hasil yang lebih detail tentang kesiapan dan pelaksanaan perkuliahan akuntansi berbasis konvergensi IFRS

\section{DAFTAR RUJUKAN}

Basuki. 2011. Metodologi Studi Kasus, Desain Penelitian. Modul. Pelatihan Metodologi Riset. 6- 7 Desember. Departemen Ekonomi Syariah. FEB Unair Surabaya.

Daftar Public Training/Workshop (http://www.lmfeui.com/index.php?page= $\underline{\text { content\&cid=49. }}$ diakses tanggal 5 Maret 2012).

Herawati, Nyoman Trisna. 2011. Konvergensi Interational Financial Reporting Standards (IFRS) dan Implikasinya Terhadap Pembelajaran Akuntansi Pengantar di Perguruan Tinggi. Jurnal Ilmiah Akuntansi dan Humanika. Vol 1 No 1. Universitas Pendidikan Ganesha. Bali

Hermawan, Sigit. 2011. Proseding Seminar Nasional dan Call For Paper 2011: Model Laporan Anggaran Berbasis Kinerja dan Tafsir Stakeholders Sekolah Menengah Atas (SMA) di Kab. Sidoarjo. Seminar Nasional Call For Paper 2011. Sidoarjo.

IFRS Resoerces, AICPA. 2012. Internasional Finansial Report Standart(http://www.ifrs.com/convergence_landing.html diakses tanggal 31 Maret 2012).

IFRS Diploma \& IFRS Certification (http://www.iaiglobal.or.id/. di akses tanggal 3 Maret 2012).

Istiningrum, Andian Ari. 2012. Experiential Learning in Introducing IFRS at Universities in Indonesia. Jurnal Economia, Vol 8 No 1, April. Fakultas Ekonomi. Universitas Negeri Yogyakarta.

Marshall, Martin N. 1996. Sampling for Qualitative Research. Family Practice, An International Journal. Vol 13, No 6. Oxford University Press.

Marshall. 2006. Data Collection Method. http://www.sagepub.com/upmdata/10985_Chapter_4.pdf. Diakses 20 Maret 20102, Jam 19.45 WIB 
Miles, Matthew B., and A Michael Huberman. 1984. Qualitative Data Analysis. Sage Publication, Inc.

Moleong, Lexy J. 2010. Metodologi Penelitian Kualitatif. PT. Remaja Rosda Karya. Bandung.

Seminar Forum Dosen Akuntansi (http://www.feb.unair.ac.id/pengumuman/393-ifrs. diakses tanggal 27 Februari 2012).

Senton, Andrew K. 2004. Strategies For Ensuring Trustworthiness in Qualitative Research Project. Education For Information. 22. 63 -75.

Slameto, 2003. Belajar dan Faktor-faktor Yang Mempengaruhinya, Rineka Cipta. Jakarta.

Situs STIE "X” Surabaya

Suhardianto, Novrys. 2011. Respon Akademisi Terhadap Konvergensi IFRS. Universitas Negeri Airlangga. Surabaya.

Supriyadi, 2013. Pendidikan Akuntansi Vokasional : Perlukah Kurikulum Berbasis IFRS ?. Simposium Nasional Akuntansi Vokasional. Denpasar Bali, 17 - 18 Mei.

Universitas "X" Sidoarjo. 2011. Buku Panduan Akademik 2011/2012. "X" Universitas Press. Sidoarjo.

Widiastuti, Harjanti. 2011. Kesiapan Dosen Akuntansi dalam Mengintegrasikan Materi IFRS dalam Mata Kuliah. Fokus Ekonomi, Vol 10 No 3. Desember. Fakultas Ekonomi. Universitas Stikubank Semarang.

www.feb.ub.ac.id. Pelatihan Pengajaran Akuntansi Keuangan Menengah Berbasis IFRS Tanggal 18 Mei 2010. (http://www.feb.ub.ac.id/pelatihan-pengajaran-akuntansikeuangan-menengah-berbasis-ifrs.html. diakses tanggal 5 Maret 2012). 